\title{
Assessing P status and trophic level of two lakes by speciation of particulate phosphorus forms
}

\author{
Uwe SELIG*, Manfred MICHALIK ${ }^{1)}$ and Thomas HÜBENER ${ }^{2)}$ \\ University of Rostock, Institute of Bio Science, Aquatic Ecology, Albert-Einstein-Straße 3, D-18051 Rostock, Germany \\ ${ }^{1)}$ University of Rostock, Institute of Catalysis Research, Albert-Einstein-Straße 29, D-18051 Rostock, Germany \\ ${ }^{2)}$ University of Rostock, Institute of Bio Science, Botany, Wismarsche Str. 8, D-18051 Rostock, Germany \\ *e-mail corresponding author: uwe.selig@biologie.uni-rostock.de
}

\begin{abstract}
Seasonal variability of dissolved and particulate $P$ forms was investigated in two lakes in Mecklenburg-Western Pomerania (North-East Germany): the polymictic Lake Bützow and the dimictic Lake Dudinghausen. Both lakes had a different trophic status according to the classic parameter total phosphorus, chlorophyll-a as well as phytoplankton biomass and composition. The aim of the study was to test P compounds and P fractions for characterization of the nutrient status of the phytoplankton, especially Polyphosphates and Phospholipids. The field study shows, that these intracellular reserve compounds in algae can not reflect the different nutrient status of the phytoplankton in the two lakes and is therefore not a more sensitive scale to indicate phosphorus limitation of plankton communities.
\end{abstract}

Key words: lake, eutrohication, phosphorus fraction, polyphosphate, phospholipid, phytoplankton biomass and composition

\section{INTRODUCTION}

Over the last decades, eutrophication of freshwater systems has been promoted by phosphorus, whose sources and bioavailability have dominated primary production (Reynolds \& Davies 2001). P availability and $\mathrm{P}$ cycles in freshwater were determined by $\mathrm{P}$ input and transformation in the pelagic subsystem and by processes at the sediment-water interface.

Phosphorus transport from the water column to the sediment is either particulate or particle associated (Tartari \& Biasci 1997). Release from the sediment takes place in dissolved or particulate form. Benthicpelagic coupling fuels primary production and nutrient availability in the water column of the euphotic zone in lakes.

Relevant publications (Fitzgerald \& Nelson 1966; Rhee 1973; Lean 1984) have demonstrated that conventional monitoring data of dissolved nutrients does not provide a sensitive indicator of the duration or degree of nutrient status and limitation in lakes. Phytoplankton is also capable of assimilating $\mathrm{P}$ from the particulate organic fraction (Cembella et al. 1984) and dissolved organic phosphorus (Cotner \& Wetzel 1992). Algae grown under resource limitation exhibit considerable variation in their biochemical composition, depending on the type of limiting nutrient and degree of limitation (Shifrin \& Chisholm 1981; Kilham et al. 1997). Accordingly, seston stoichiometry has been proposed as an indicator for limiting nutrients (Sommer 1989; Urabe 1993). The variability of the $C: N: P$ ratio in marine microalgae was described (Banse 1974a; Geider \& La Roche 2002) for the interpretation of nutrient deficiency of microalgae in aquatic systems. Especially in shallow lakes with abundant resuspended particles, the nutrient stoichoimetry cannot characterize limitation conditions.

Phosphorus can be stored as polyphosphate granules; these serve as an energy and phosphate reserve (Kornberg 1995) and have been detected in eubacteria, fungi, algae, protozoans and in various tissues of plants and animals (Kulaev \& Vagabov 1983). These granules only accumulate under a sufficient P supply. Polyphosphate granules in algal cells have therefore been used to indicate high phosphorus loads in the water body (Schelske \& Sicko-Goad 1990) and to reconstruct the trophic development of lakes based on sediment analyses (Kenney et al. 2001).

This field study was designed to investigate the seasonal variation of different forms of phosphorus in two lakes with different mixis and eutrophic status. Besides the dissolved and total phosphorus concentration, Pbinding forms, polyphosphates and phospholipids as reserve compounds were analysed to characterise the $P$ status of phytoplankton communities. The hypothesis was that internal $\mathrm{P}$ compounds - especially polyphosphates and phospholipids - are a sensitive indicator of $\mathrm{P}$ status of phytoplankton communities and helpful for lake monitoring and lake management by restoration projects.

\section{METHODS}

\subsection{Study site}

Lake Bützow and Lake Dudinghausen are located in Mecklenburg-Western Pomerania (North-East Germany), approximately $40 \mathrm{~km}$ southwest and south of 


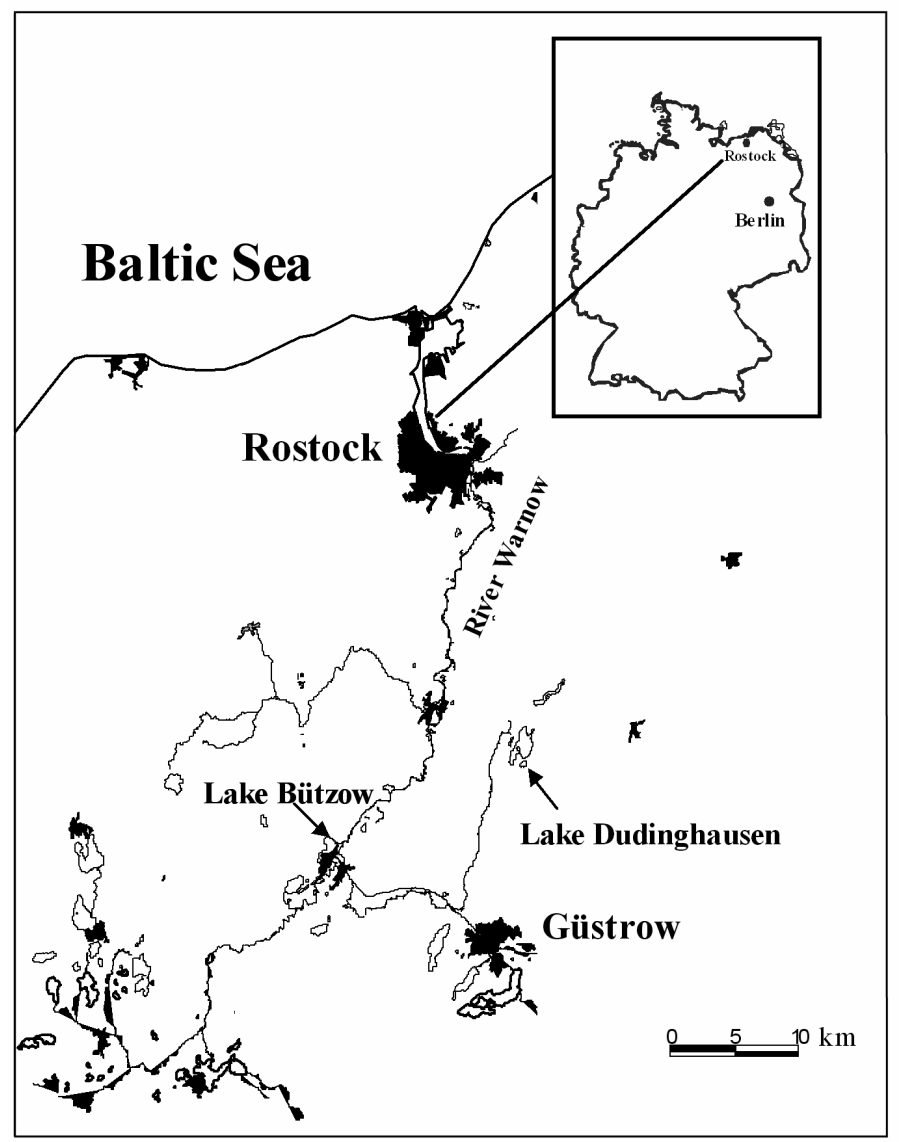

Fig. 1. Geographic location of Lake Bützow and Lake Dudinghausen in Northern Germany.

Tab. 1. Morphometric and limnological characteristics of both lakes.

\begin{tabular}{lcc}
\hline & Lake Bützow & Lake Dudinghausen \\
\hline Morphometric parameter & & \\
Surface area in ha & 98.1 & 18.8 \\
Volume [m ${ }^{3}$ ] & 1.02106 & 1.29106 \\
Mean depth [m] & 1.0 & 6.9 \\
Maximum depth [m] & 2.2 & 15.2 \\
Mixis & polymictic & dimictic \\
Physico-chemical parameter & & \\
O $_{2}$ saturation [\%] (water surface) & $59-161$ & $63-129$ \\
Secchi disk depth [m] & $0.3-0.7$ & $0.6-3.6$ \\
pH (water surface) & $8.0-9.4$ & $7.9-8.8$ \\
Trophic classification 1995/1996 & eutrophic & mesotrophic \\
\hline
\end{tabular}

Rostock (Fig. 1). The main morphometric and limnological parameters of both lakes are presented in table 1. Lake Bützow is classified as eutrophic, Lake Dudinghausen as mesotrophic according to the German standard (Lawa 1998) and the OECD (1982) criteria. Both represent two typical lake types in North-East Germany: shallow lake with a polymictic circulation and deeper lake with a dimictic thermic stratification. Lake Bützow is a shallow lake situated on a tributary of the Warnow River (Selig et al. 2002). Sixty percent of the catchment area from the Warnow River is intensively used by agriculture and the nutrient input from the catchments area is high: an average of $4430 \mathrm{t}$ of $\mathrm{N}$ and $90 \mathrm{t}$ of $\mathrm{P}$ annually (Behrendt 1996). Separate data for the Lake Bützow no exist. In contrast Lake Dudinghausen has a thermic stratification and anoxic hypolimnion during the summer (Selig et al. 2004). The catchments area is small $\left(<16 \mathrm{~km}^{2}\right)$ and the most input of nutrients comes from the groundwater (Dressler et al. 2006).

\subsection{Sampling}

Water temperature, $\mathrm{pH}$ and dissolved oxygen were measured in the surface water $(0.5 \mathrm{~m})$ in the shallow Lake Bützow and in $0.5 \mathrm{~m}, 1 \mathrm{~m}$ and then in $1 \mathrm{~m}$ steps down to the bottom in the dimictic Lake Dudinghausen 
with the multiprobe Torphil 406 (Remember eG, Germany). Nutrient concentrations and phytoplankton counts were determined in the same steps in both lakes, but only presented here for the surface water $(0.5 \mathrm{~m})$ for the direct comparison of both lakes. Results of the vertical distribution of nutrients and plankton in Lake Dudinghausen were described in Selig et al. (2004) separately. Samples were kept at $4{ }^{\circ} \mathrm{C}$ in the dark and analysed within the next 3-5 h.

\subsection{Nutrient analysis}

Soluble reactive phosphorus (SRP) was analysed after membrane filtration $(0.45 \mu \mathrm{m})$ by applying the molybdenum blue method in a flow-through system at $660 \mathrm{~nm}$ according to Malcom-Lawes and Koon (1990). Total phosphorus (TP) was analysed from the unfiltrated sample as SRP after acid hydrolysis under UV irradiation and determined after the molybdenum blue method according to Nakamura et al. (1980). Benson et al. (1996) compared this flow injection method and found a good agreement to the conventional batch digestion method.

Aliquots of water samples were filtered (Whatman $\mathrm{GF} / \mathrm{F}$ ) and the filter subsequently dried (at $60{ }^{\circ} \mathrm{C}$ for 24 h) to determine particulate matter. Particulate organic carbon (POC) and particulate nitrogen (PN) were analysed with a $\mathrm{C} / \mathrm{N}$ Analyser vario EL after Verardo et al. (1990). Particulate phosphorus (PP) was determined as the $\mathrm{HCl}$-soluble residues after heating at $500{ }^{\circ} \mathrm{C}$ (Andersen 1976). The authors described a high reproducibility of this ignition method with the conventional perchloric acid method. HCl-soluble particulate iron (PFe) was measured in the extract after Stookey (1970).

\subsection{Chlorophyll-a and phytoplankton analysis}

Chlorophyll- $a(\mathrm{Chl}-a)$ was extracted in ethanol according to DEV (1985). 500 to $1000 \mathrm{ml}$ of the sample was glass fibre filtered. The filter was rubed and put into boiled ethanol. After $20 \mathrm{~h}$ in darkness the suspension was centrifugated. At first the supernatant was measured at 663 and $750 \mathrm{~nm}$. For differentiation of degradation compounts of Chl- $a$ (phaeophytine- $a$ ) it follows an acidification $(0.1 \mathrm{M} \mathrm{HCl})$ and a replication of the measurement at 663 and $750 \mathrm{~nm}$. Phytoplankton biomass was analysed according to Utermöhl (1958). Abundant species were counted to 100 units at least. The biovolume of dominant species was determined by measuring the dimensions of 10 counting units and calculating to the closest geometrical figure (Edler 1979). Biovolume was transformed into fresh-weight biomass based on a mean density of $1 \mathrm{~g} \mathrm{~cm}^{-3}$.

\subsection{Sequential $P$ extraction and special $P$ analysis}

The extraction method of Psenner et al. (1984) was used to analyse the different forms of phosphorus in particulate matter. The extractants were applied in the following sequence: $\mathrm{H}_{2} \mathrm{O}$ (distilled water, $20 \mathrm{~min}$ ), 0.11
M BD (bicarbonate dithionite, $30 \mathrm{~min}$ ), $1 \mathrm{M} \mathrm{NaOH}$ (16 h), $0.5 \mathrm{M} \mathrm{HCl}(16 \mathrm{~h})$. The extractants were separated from the residues by centrifugation at $4000 \mathrm{~g}$ for 20 min. The soluble reactive phosphorus (SRP) was analysed in each extractant. Total phosphorus (TP) was determined as SRP in the extractant after acid hydrolysis under UV irradiation. The non-reactive phosphorus (NRP) is the difference between TP and SRP. Fractions were defined as follows: $\mathrm{H}_{2} \mathrm{O}-\mathrm{TP}$ as available phosphorus, BD-SRP extract as reductant soluble phosphorus, $\mathrm{NaOH}-\mathrm{SRP}$ as sorptive bound phosphorus, NaOH-NRP as organic bound phosphorus and HCl-SRP as carbonate bound phosphorus. SRP and TP were analysed no later than $6 \mathrm{~h}$ after extraction, after the sample was neutralized. Blanks and references were prepared by extracting filters without samples.

For determination of polyphosphate (polyP), the samples were extracted with $2 \mathrm{~N} \mathrm{KOH}$ containing $30 \mathrm{mg}$ EDTA $\mathrm{ml}^{-1}$ according to Feuillade et al. (1995). The ${ }^{31} \mathrm{P}-\mathrm{NMR}$ spectra were recorded on a Bruker ARX-300 spectrometer (12.5 MHz, 3000-4000 scans) described by Selig et al. (2002). Phospholipids (Plipid) were extracted in chloroform/methanol after the method of Findlay et al. (1989) modified for suspended matter. Plipid was determined after decomposition $\left(\mathrm{K}_{2} \mathrm{HSO}_{4}\right)$ and neutralisation as soluble reactive phosphorus (SRP) with the molybdenum blue method followed the description of nutrient analysis.

\section{RESULTS}

\subsection{TP, SRP and Chl a analysis}

TP concentration in the surface water layer was lower in Lake Dudinghausen (19-68 $\mu \mathrm{g}^{-1}$ ) than in Lake Bützow (93-298 $\mu \mathrm{g} \mathrm{l}^{-1}$, Fig. 2). In the former, the highest values were recorded in spring and autumn, whereas in the latter the values were higher in summer. The SRP concentration was 5-28 $\mu \mathrm{g}^{-1}$ in Lake Dudinghausen and 13-74 $\mu \mathrm{g} \mathrm{l}^{-1}$ in Lake Bützow. The Chl- $a$ concentration, which was measurable throughout the year, was under $16 \mu \mathrm{g}^{-1}$ in Lake Dudinghausen, with maximum concentration in spring and summer. In Lake Bützow, Chl- $a$ varied between 10 and $90 \mu \mathrm{gl}^{-1}$.

\subsection{CNP analysis}

The POC, PN, PP and PFe concentrations were lower in Lake Dudinghausen (Tab. 2). The ratio between the particulate nutrients shows a different picture: the POC/PN ratio was generally higher in Lake Dudinghausen, whereas the $\mathrm{PFe} / \mathrm{PP}$ ratio was consistently higher in Lake Bützow. Neither lake showed clearly higher POC/PP and PN/PP values. In summer - during thermic stratification - the ratios were higher in Lake Dudinghausen. A high correlation was found between $\mathrm{PP}$ and PFe in both lakes (and also between POC and PP in Lake Dudinghausen, Tab. 3). 

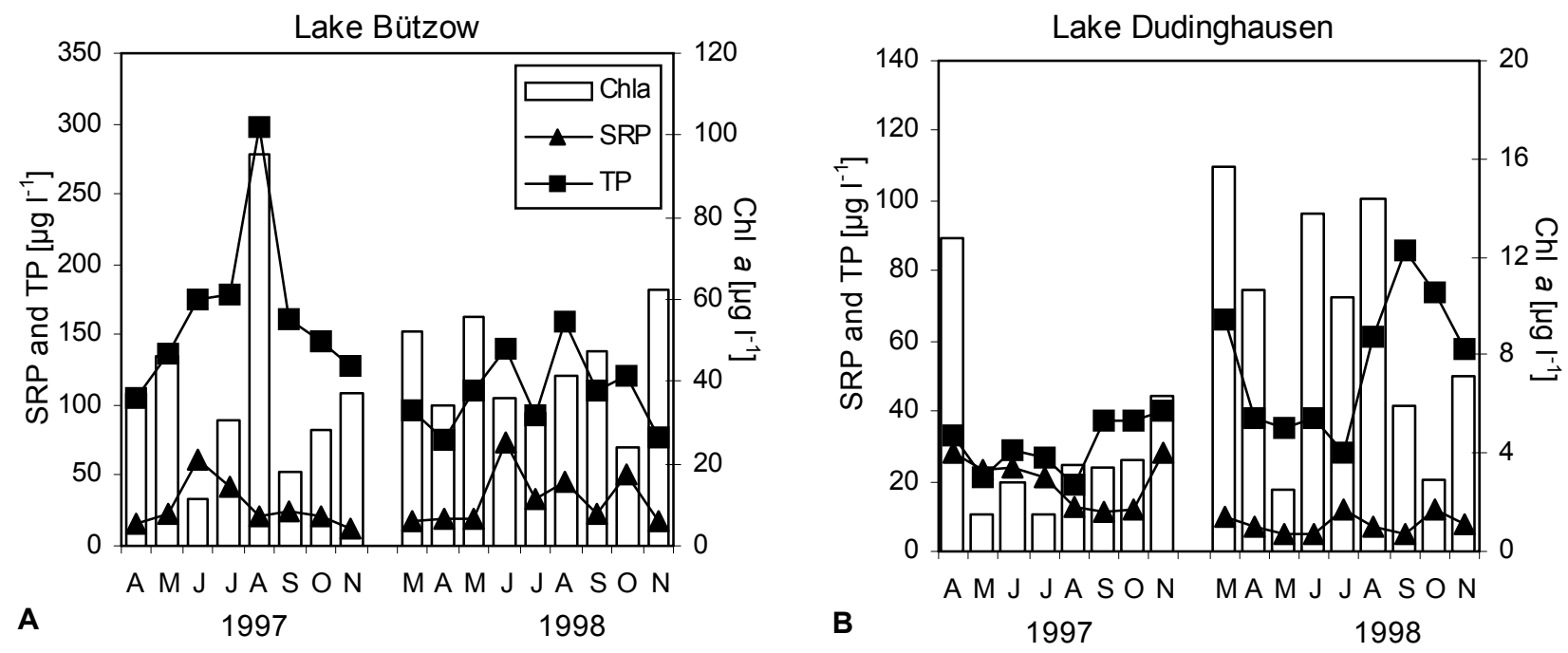

Fig. 2. SRP, TP and Chl- $a$ concentration in 1997 and 1998 in Lake Bützow (A) and Lake Dudinghausen (B).

Tab. 2. Concentration of POC, PN, PP and PFe in both lakes and the molar ratio ( $\mu \mathrm{mol}: \mu \mathrm{mol})$ of these particulate nutrients during 1998.

\begin{tabular}{|c|c|c|c|c|c|c|c|c|}
\hline & $\begin{array}{c}\mathrm{POC} \\
{\left[\mathrm{mg} \mathrm{l}^{-1}\right]}\end{array}$ & $\begin{array}{c}\mathrm{PN} \\
{\left[\mathrm{mg} \mathrm{1}^{-1}\right]}\end{array}$ & $\begin{array}{c}\mathrm{PP} \\
{\left[\mathrm{mg} \mathrm{l}^{-1}\right]}\end{array}$ & $\begin{array}{c}\mathrm{PFe} \\
{\left[\mathrm{mg} \mathrm{l}^{-1}\right]}\end{array}$ & $\begin{array}{c}\mathrm{POC} / \mathrm{PN} \\
\text { molar }\end{array}$ & $\begin{array}{l}\mathrm{POC} / \mathrm{PP} \\
\text { molar }\end{array}$ & $\begin{array}{l}\mathrm{PN} / \mathrm{PP} \\
\text { molar }\end{array}$ & $\begin{array}{c}\mathrm{PFe} / \mathrm{PP} \\
\text { molar }\end{array}$ \\
\hline \multicolumn{9}{|c|}{ Lake Bützow } \\
\hline March & 4.2 & 0.7 & 0.051 & 0.066 & 7.2 & 213.9 & 29.7 & 0.72 \\
\hline April & 4.2 & 0.7 & 0.048 & 0.067 & 6.7 & 227.1 & 34.1 & 0.77 \\
\hline May & 4.8 & 1.0 & 0.112 & 0.101 & 5.6 & 110.9 & 20.0 & 0.51 \\
\hline June & 3.2 & 0.7 & 0.087 & 0.128 & 5.3 & 102.8 & 19.4 & 0.81 \\
\hline July & 3.6 & 0.7 & 0.074 & 0.073 & 6.4 & 126.7 & 19.7 & 0.55 \\
\hline August & 3.0 & 0.6 & 0.067 & 0.052 & 5.8 & 115.3 & 19.9 & 0.43 \\
\hline September & 3.6 & 0.7 & 0.054 & 0.067 & 6.0 & 173.3 & 29.0 & 0.69 \\
\hline October & 1.9 & 0.4 & 0.039 & 0.097 & 5.8 & 127.5 & 22.1 & 1.37 \\
\hline November & 2.9 & 0.6 & 0.041 & 0.074 & 5.8 & 182.1 & 31.6 & 1.00 \\
\hline \multicolumn{9}{|c|}{ Lake Dudinghausen } \\
\hline March & 1.7 & 0.2 & 0.022 & 0.006 & 9.0 & 203.1 & 22.5 & 0.15 \\
\hline April & 1.8 & 0.3 & 0.038 & 0.046 & 8.0 & 123.5 & 15.5 & 0.69 \\
\hline May & 0.6 & 0.1 & 0.010 & 0.002 & 6.6 & 149.4 & 22.8 & 0.11 \\
\hline June & 1.6 & 0.2 & 0.013 & 0.005 & 7.8 & 310.5 & 39.9 & 0.21 \\
\hline July & 2.2 & 0.3 & 0.026 & 0.012 & 7.9 & 212.3 & 26.8 & 0.25 \\
\hline August & 1.9 & 0.2 & 0.019 & 0.007 & 12.6 & 259.5 & 20.7 & 0.21 \\
\hline September & 1.5 & 0.2 & 0.014 & 0.006 & 9.4 & 276.2 & 29.4 & 0.23 \\
\hline October & 0.7 & 0.1 & 0.013 & 0.008 & 6.6 & 132.0 & 20.0 & 0.33 \\
\hline November & 0.8 & 0.1 & 0.011 & 0.009 & 6.7 & 174.0 & 25.9 & 0.44 \\
\hline
\end{tabular}


Tab. 3. Correlation coefficients (Pearson coefficient as $r^{2}, \alpha=0.05$ ) for particulate nutrients, phytoplankton biomass (PB), Chl- $a$, Plipid and the dominant P-fraction; bold figures show the coefficients above 0.4 .

\begin{tabular}{|c|c|c|c|c|c|c|c|c|c|c|c|c|}
\hline & & POC & $\mathrm{PP}$ & $\mathrm{PFe}$ & PB & Chl- $a$ & P-Lipid & BD-SRP & $\mathrm{NaOH}-\mathrm{NRP}$ & $\mathrm{NaOH}-\mathrm{SRP}$ & $\Sigma \mathrm{SRP}$ & $\Sigma \mathrm{NRP}$ \\
\hline $\begin{array}{l}\text { Lake Bützow } \\
\text { Lake Dudinghausen }\end{array}$ & POC & ------ & $\begin{array}{l}0.04 \\
\mathbf{0 . 4 6}\end{array}$ & $\begin{array}{l}0.09 \\
0.09\end{array}$ & $\begin{array}{c}<0.01 \\
0.28\end{array}$ & $\begin{array}{c}<0.01 \\
\mathbf{0 . 6 1}\end{array}$ & $\begin{array}{l}0.02 \\
0.09\end{array}$ & $\begin{array}{l}0.03 \\
0.07\end{array}$ & $\begin{array}{l}0.15 \\
0.01\end{array}$ & $\begin{array}{c}0.04 \\
<0.01\end{array}$ & $\begin{array}{c}0.19 \\
<0.01\end{array}$ & $\begin{array}{l}0.13 \\
0.23\end{array}$ \\
\hline $\begin{array}{l}\text { Lake Bützow } \\
\text { Lake Dudinghausen }\end{array}$ & $\mathrm{PP}$ & & ------ & $\begin{array}{l}0.25 \\
\mathbf{0 . 7 3}\end{array}$ & $\begin{array}{l}<0.01 \\
<0.01\end{array}$ & $\begin{array}{l}0.02 \\
0.20\end{array}$ & $\begin{array}{l}0.01 \\
0.01\end{array}$ & $\begin{array}{l}0.12 \\
0.06\end{array}$ & $\begin{array}{l}0.44 \\
0.15\end{array}$ & $\begin{aligned} & 0.3 \\
< & 0.01\end{aligned}$ & $\begin{array}{l}\mathbf{0 . 4 9} \\
0.05\end{array}$ & $\begin{array}{l}0.15 \\
0.31\end{array}$ \\
\hline $\begin{array}{l}\text { Lake Bützow } \\
\text { Lake Dudinghausen }\end{array}$ & $\mathrm{PFe}$ & & & ------ & $\begin{array}{l}0.05 \\
0.05\end{array}$ & $\begin{array}{l}0.03 \\
0.02\end{array}$ & $\begin{array}{c}<0.01 \\
0.08\end{array}$ & $\begin{array}{l}\mathbf{0 . 6 5} \\
0.29\end{array}$ & $\begin{array}{l}0.31 \\
0.22\end{array}$ & $\begin{array}{l}0.35 \\
0.02\end{array}$ & $\begin{array}{l}\mathbf{0 . 4 4} \\
0.02\end{array}$ & $\begin{array}{l}0.27 \\
0.08\end{array}$ \\
\hline $\begin{array}{l}\text { Lake Bützow } \\
\text { Lake Dudinghausen }\end{array}$ & PB & & & & ------ & $\begin{array}{l}0.13 \\
0.38\end{array}$ & $\begin{array}{l}\mathbf{0 . 6 7} \\
0.06\end{array}$ & $\begin{array}{c}<0.01 \\
0.03\end{array}$ & $\begin{array}{l}0.11 \\
0.02\end{array}$ & $\begin{array}{c}0.27 \\
<0.01\end{array}$ & $\begin{array}{c}0.19 \\
<0.01\end{array}$ & $\begin{array}{c}0.03 \\
<0.01\end{array}$ \\
\hline $\begin{array}{l}\text { Lake Bützow } \\
\text { Lake Dudinghausen }\end{array}$ & Chl- $a$ & & & & & ------ & $\begin{array}{l}<0.01 \\
<0.01\end{array}$ & $\begin{array}{c}<0.01 \\
0.05\end{array}$ & $\begin{array}{l}0.05 \\
0.15\end{array}$ & $\begin{array}{l}0.02 \\
0.01\end{array}$ & $\begin{array}{c}0.01 \\
<0.01\end{array}$ & $\begin{array}{c}0.02 \\
<0.01\end{array}$ \\
\hline $\begin{array}{l}\text { Lake Bützow } \\
\text { Lake Dudinghausen }\end{array}$ & P-Lipid & & & & & & ------ & $\begin{array}{c}<0.01 \\
0.16\end{array}$ & $\begin{array}{l}0.15 \\
0.04\end{array}$ & $\begin{array}{l}0.16 \\
0.30\end{array}$ & $\begin{array}{l}0.18 \\
0.04\end{array}$ & $\begin{array}{c}<0.01 \\
0.18\end{array}$ \\
\hline $\begin{array}{l}\text { Lake Bützow } \\
\text { Lake Dudinghausen }\end{array}$ & BD-SRP & & & & & & & ------ & $\begin{array}{l}0.22 \\
0.03\end{array}$ & $\begin{array}{l}\mathbf{0 . 4 9} \\
0.07\end{array}$ & $\begin{array}{l}0.31 \\
0.29\end{array}$ & $\begin{array}{l}\mathbf{0 . 7 7} \\
0.06\end{array}$ \\
\hline $\begin{array}{l}\text { Lake Bützow } \\
\text { Lake Dudinghausen }\end{array}$ & $\mathrm{NaOH}-\mathrm{NRP}$ & & & & & & & & ----- & $\begin{array}{l}\mathbf{0 . 4 4} \\
0.31\end{array}$ & $\begin{array}{l}\mathbf{0 . 5 9} \\
0.04\end{array}$ & $\begin{array}{l}0.07 \\
0.04\end{array}$ \\
\hline $\begin{array}{l}\text { Lake Bützow } \\
\text { Lake Dudinghausen }\end{array}$ & $\mathrm{NaOH}-\mathrm{SRP}$ & & & & & & & & & ------ & $\begin{array}{l}0.59 \\
0.83\end{array}$ & $\begin{array}{l}0.07 \\
0.13\end{array}$ \\
\hline $\begin{array}{l}\text { Lake Bützow } \\
\text { Lake Dudinghausen }\end{array}$ & $\Sigma \mathrm{SRP}$ & & & & & & & & & & ------ & $\begin{array}{l}0.24 \\
0.09\end{array}$ \\
\hline $\begin{array}{l}\text { Lake Bützow } \\
\text { Lake Dudinghausen }\end{array}$ & $\Sigma \mathrm{NRP}$ & & & & & & & & & & & ------ \\
\hline
\end{tabular}

Lake Bützow

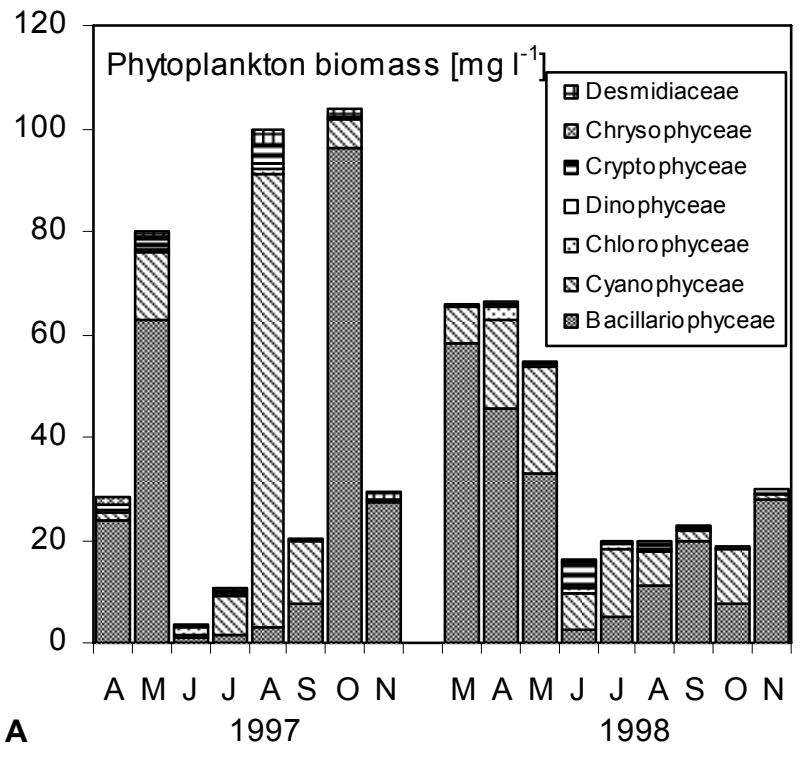

Lake Dudinghausen

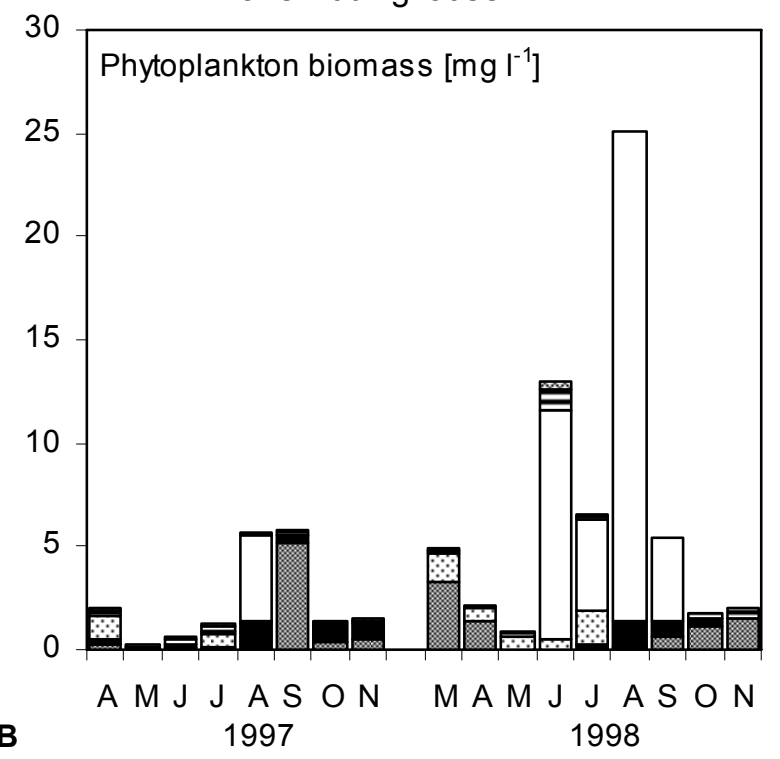

Fig. 3. Seasonal variability of phytoplankton dominance in Lake Bützow (A) and Lake Dudinghausen (B) in 1997 and 1998.

\subsection{Plankton communities}

The highest phytoplankton biomass $\left(109 \mathrm{mg}^{-1}\right)$ was found in Lake Bützow, with a high variability. The values were higher than in the surface layer in Lake Dudinghausen (1 to $25 \mathrm{mg} \mathrm{l}^{-1}$, Fig. 3). In Lake Bützow the seasonal variation was very different in both investigation years: in 1997 biomass peaked in summer, in 1998 in spring. In both years the dominances changed between Bacillariophyceae (spring and autumn) und Cyanobacteria (summer).

In Lake Dudinghausen a summer phytoplankton biomass peak was typical for both years, yet with different values. In 1998, high Dinophycae biomass (mainly Ceratium hirundinella) dominated the phytoplankton with a maximum of $23 \mathrm{mg} \mathrm{l}^{-1}(92 \%$ of the 

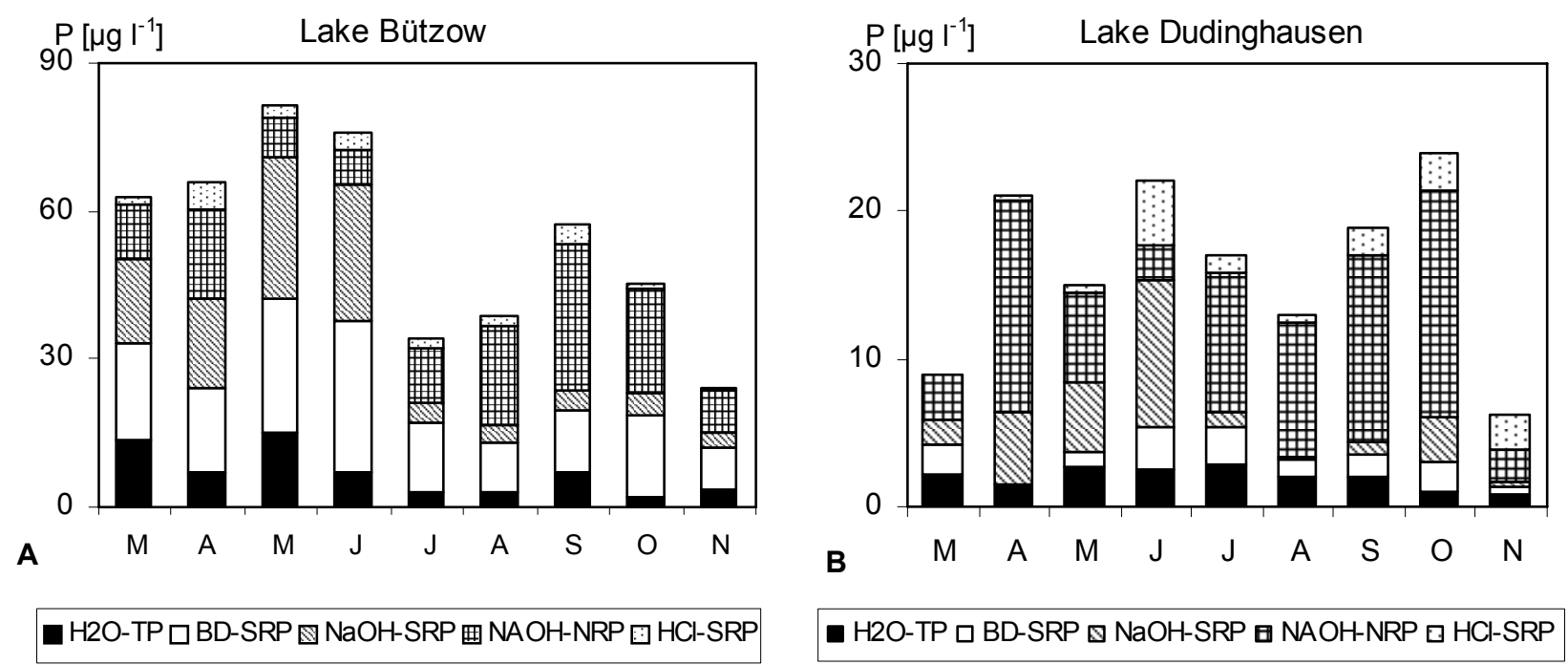

Fig. 4. Seasonal variation of the particulate phosphorus fraction in the surface water of Lake Bützow (A) and Lake Dudinghausen (B) from March to November 1998.
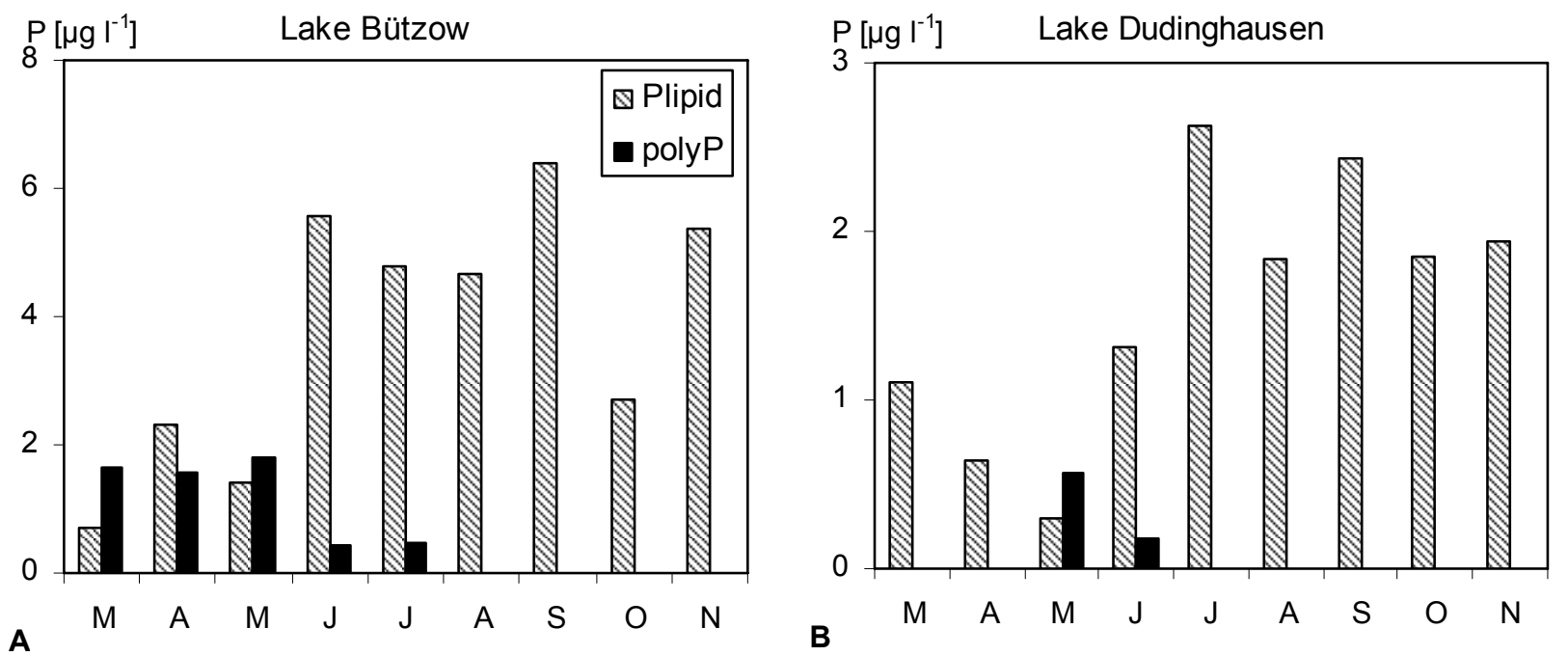

Fig. 5. Concentrations of polyphosphate (PolyP) and phospholipid (P-lipid) in Lake Bützow (A) and Lake Dudinghausen (B) from March to November 1998.

phytoplankton communities). In 1997, Dinophycae also dominated in August, but with a much lower biomass. In 1997 the dominance in the phytoplankton community had the following seasonal sequence: Bacillariophyceae, Chlorophyta, Dinophyceae, Cyanobacteria and Bacillariophyceae.

\subsection{Sequential extraction of PP and P-forms}

Figure 4 illustrates the seasonal distribution of the phosphorus fractions in both lakes. The dominant fraction and the variability differed considerably in both lakes. In Lake Bützow the dominance changed between the BD-SRP and $\mathrm{NaOH}-\mathrm{SRP}$ fraction until June, whereas from August to October, NaOH-NRP dominated with $39-42 \%$ of the $\mathrm{PP} . \mathrm{H}_{2} \mathrm{O}$-extractable $\mathrm{P}$ con- tributed $4-20 \%$. The highest concentration of this fraction was measured towards the end of the spring phytoplankton peak in May.

$\mathrm{NaOH}-\mathrm{NRP}$ dominated (except in June) in Lake Dudinghausen. The percentage values ranged from 10 to $65 \%$ PP. NaOH-SRP was higher in spring and dominated with 44\% PP in June. BD-SRP and HCl-SRP played a minor role with respect to the $\mathrm{PP}$ in Lake Dudinghausen.

PolyP - as the internal reserve compound of organisms - could only be detected in the first half year (until July) in Lake Bützow; its percentage decreased during the year and amounted to $1.6-4.2 \%$ of PP (Fig. 5A). In Lake Dudinghausen, polyP was only determined in May and June, making up only 8 and $9 \%$ of the organic P fraction (Fig. 5B). 
The Plipid content, however, increased in June/July in both lakes and remained constant to the end of the study period. The values ranged from $1-9 \%$ of PP in both lakes. During the second half of 1998, the Plipids formed 78 and $68 \%$ of the organic $\mathrm{P}(\mathrm{NaOH}-\mathrm{NRP}$ fraction) in June and November in Lake Bützow, respectively. In Lake Dudinghausen the Plipids varied between 4 and $88 \%$ of the organic $\mathrm{P}$, with a maximum in November. In Lake Bützow the Plipid content was highly correlated with the phytoplankton biomass (Tab. 3).

\section{DISCUSSION}

\subsection{Trophic level}

TP, Chl- $a$ and phytoplankton biomass are the classical parameters to classify the trophic level of lakes. Accordingly, both lakes have a clearly different trophic status: Lake Bützow is eutrophic and Lake Dudinghausen is mesotrophic. In shallow lakes the German standard method for lake classification cannot be used because the parameters secchi disk depth and TP are influenced by sediment resuspension. Phytoplankton biomass clearly described the high trophic level for Lake Bützow. Besides the biomass, the dominant taxonomical classes were also different in both lakes. Thus, the phytoplankton biomass, the algae species and the seasonal variation described the different trophic level of the two lakes. The seasonal variation of algae groups was confirmed in both investigations years, but the phytoplankton biomass was very different.

The SRP concentration also characterised the different nutrient status of both lakes. In Lake Dudinghausen the SRP concentrations were below 12 $\mu \mathrm{g} \mathrm{l}^{-1}$ in 1998, whereas in Lake Bützow the values never fell under $10 \mu \mathrm{g} \mathrm{l}^{-1}$. Sas (1989) concluded that the seasonal mean concentration must drop below $10 \mu \mathrm{g} \mathrm{l}^{-1}$ to reduce phytoplankton biomass. Resuspension may explain the high SRP concentration and the bioavailable phosphorus in Lake Bützow. Sediment resuspension has been described as a potential source of nutrients for phytoplankton in shallow lakes (Carper \& Bachmann 1984; Canfield \& Hoyer 1988; Hamilton \& Mitchell 1997). In Lake Dudinghausen, P can be released from the sediment under anoxic conditions only in the hypolimnion during summer stratification (Selig \& Schlungbaum 2003).

\subsection{Elemental ratios in particulate matter}

In contrast to the SRP concentration, the elemental composition (C/N/P ratio) of particulate matter showed a phosphorus deficiency corresponding to the Redfield ratio for phytoplankton growth throughout both years in both lakes. Hecky and Kilham (1988) described particle composition as the simplest and most comparable way of defining the nutrient status of phytoplankton. Banse (1974b) has dealt with the interpretation of the elemental ratio in marine systems. These results would also apply to limnic systems. The $\mathrm{C} / \mathrm{P}$ ratio failed to describe the different nutrient status of the two lakes. Particulate matter in lakes was higher and more variable in elemental ratios than particulate matter in oceans (Hecky et al. 1993). Especially in shallow lakes, particulate matter consists of plankton, detritus, allochthonous particles and resuspended sediments. The correlation analysis showed a strong relation between POC and Chl- $a$. For Lake Bützow, no relation between the phytoplankton biomass and Chl- $a$ concentration was found. The relation of particulate nutrients does not reflect the nutrient status of planktonic organisms in the shallow Lake Bützow. Therefore, this classic parameter of defining the nutrient status of phytoplankton is insufficient to compare shallow lakes with dimictic lakes.

Moreover, the total pool of PP is not available for algal growth in either lake type. Reynolds and Davies (2001) described the ideal instantaneous measure of P bioavailability as the sum of SRP and biomass phosphorus. Chemical extraction was used to define the bioavailable P (Young \& DePinto 1982; Dorich et al. 1985; House et al. 1995; Fabre et al. 1996). The interpretation of these results varied strongly depending on the extraction protocols.

\subsection{P-Fractionation}

The P-fractionation, based on Psenner et al. (1984), is used to define the released and available $\mathrm{P}$ depending on the variation of environmental conditions in lake water and sediment, especially depending on variation of oxygen conditions. This fractionation procedure has been used to describe the transformation of particulate phosphorus in both: the sediment and the water body (Hupfer et al. 1995; Pacini \& Gächter 1999). Thus, it can better describe $\mathrm{P}$ availability under different conditions in lake water than the fractionation procedure that subdivides the intracellular phosphorus components such as sugar P or nucleic P (Miyata \& Hattori 1986). Independent of this fractionation procedure, the two internal P compounds polyP and Plipid were separately determined.

Based on the definition of Boström et al. (1988), the sum of $\mathrm{H}_{2} \mathrm{O}-\mathrm{TP}$ and $\mathrm{NaOH}-\mathrm{NRP}$ is the available PP in the pelagic subsystem. Accordingly, $31-76 \%$ of the PP in Lake Bützow and 22-85\% PP in Lake Dudinghausen was available for autotrophic organisms during the vegetation season. This analysis indicates no $P$ limitation at any time in either pelagic system. BD-SRP as well as $\mathrm{NaOH}-\mathrm{SRP}$, which are defined as being available for overlying sediments (Boström 1984), must be characterised as stably bound and unavailable for autotrophic organisms in the oxic water column (Selig 2003). 
The inorganic $\mathrm{P}$ fraction is only important in Lake Bützow. This reflects the suspended particulate matter in this shallow lake. The relation between PP and PFe was very different in both lakes. Whereas for Lake Dudinghausen no correlations $\left(r^{2}=0.25\right)$ were found, the correlation was high in Lake Bützow $\left(r^{2}=0.75\right)$. In the shallow lake we also found a correlation of PFe with the BD-SRP fraction. Pacini and Gächter (1999) described the high importance of BD-SRP in riverine particulate phosphorus during rain events. This fraction characterised the phosphorus binding on particles and showed that colloidal $\mathrm{Fe}$ is associated with colloidal $\mathrm{P}$. Whereas the BD-SRP fraction in rivers was increased by higher discharges, in shallow lakes it was primarily increased by resuspension processes. Therefore, the resuspension of muddy sediment particles and the benthic-pelagic coupling influences the $\mathrm{P}$ binding and $\mathrm{P}$ availability in the pelagic zone of shallow Lake Bützow.

\subsection{Polyphosphate and phospholipid as internal $P$ compounds}

It has been postulated that the content of polyphosphates in microalgae can be used as a biological indicator for higher $\mathrm{P}$ loading and eutrophication. The analysis of TP, Chl- $a$ and phytoplankton biomass clearly describe the different trophic status of both lakes. In spite of the also high SRP concentration and higher proportion of available $\mathrm{P}$ in the PP, polyphosphate granules were only determined in the first half of each year in the eutrophic Lake Bützow. In Lake Dudinghausen, polyP was only detectable in May and June. Therefore, the analysis of polyP is not confirmed with the different $\mathrm{P}$ status and trophic level in both lakes. In freshwater, such reserve compounds have mostly been reported from nutrient-rich waters. For example, Schelske and Sicko-Goad (1990) observed these compounds in bays of Lake Michigan with heavy nutrient load and described their influence on phytoplankton dynamics. Schelske (1994) excluded a P-limitation in the shallow Lake Apopka based on polyphosphate granules, which were found year-round in algae. The same effect could not be found in the also high eutrophic shallow Lake Bützow in our results. Lean (1984) showed that for about a month after SRP concentrations fell, the $\mathrm{P}$ stored within the cells could have met the demands of the phytoplankton. Kenney et al. (2001) interpreted polyphosphate accumulation in the sediment as an effect of high P load and as accumulation of storage in algae cells. All these authors used polyphosphate granules as an indicator for systems that are sufficiently supplied with phosphorus that is available for algae. Bolier et al. (1992) found polyP in phytoplankton cells - independent of the SRP concentration and without prior P starvation - in different parts of the Andelse Maas basin. The present investigation of Lake Dudinghausen and Lake Bützow also shows that polyP granules cannot be used to characterise the differ- ent trophic status and $\mathrm{P}$ availability in both systems. Eixler et al. (2006) investigated the accumulation of phosphorus storage in Chlorella vulgaris and its dependence on phosphate supply in laboratory experiments. The variation in phosphate concentration in the medium of a well supplied culture had much less effect on the degree of polyP storage than a preceding P starvation phase. These results from laboratory studies confirm the field study of Lake Bützow and Lake Dudinghausen.

The accumulation of polyP in freshwater ecosystems was observed more at the sediment-water interface (Davelaar 1993) or on the thermocline and chemocline in dimictic lakes (Selig et al. 2004). In P-rich wastewater systems the absence of polyP accumulation by organisms has been discussed as reflecting stress situations (Kjeldstad et al. 1991; Lawrence et al. 1998). The higher accumulation rate of polyP in the post-stress condition is among the discussed effects. Feuillade et al. (1995) observed a higher polyP concentration in Chlorella $\mathrm{sp}$. in the recovery period after $\mathrm{P}$ starvation. We cannot explain the presence of the polyP only in the spring in both lakes, and can only speculate at this point in time. We postulated, that permanent or temporary light limitation is a potential stress factor for the phytoplankton in shallow lakes - also for Lake Bützow (Secchi disk depth lower $0.4 \mathrm{~m}$ during the whole vegetation period).

In contrast to polyP granules, Plipids are indicators of microbial biomass (Findlay et al. 1989). According to Napolitano (1994), Plipid content varied substantially and unpredictably among algae and periphyton under different light regimes. Irradiance also had a significant effect on storage lipids. In the shallow lake we found a strong similarity between phytoplankton biomass and Plipid concentration. This, however, is not valid for the dimictic Lake Dudinghausen. Moreover, no relationship of Plipid to Chl- $a$ or to POC was found. Therefore, the Plipids cannot generally be used to detect plankton biomass in freshwater. The relation of Plipids to other $\mathrm{P}$ compounds - such as PP, the $\mathrm{P}$ fraction or polyP - provides no information about the $\mathrm{P}$ status of phytoplankton and $\mathrm{P}$ availability.

\section{ACKNOWLEDGMENTS}

All this would not have been possible without Fred Brezsinski's technical assistance in the field. We thank Sabine Stolle and Regine Paschen for technical assistance in the laboratory.

\section{REFERENCES}

Andersen, J.M. 1976. Ignition method for determination of total phosphorus in lake sediments. Wat. Res., 10: 329331.

Banse, K. 1974a. On the interpretation of data for the carbonto-nitrogen ratio of phytoplankton. Limnol. Oceanogr., 19: 695-699. 
Banse, K. 1974b. The nitrogen-to-phosphorus ratio in the photic zone of the sea and the elemental composition of the plankton. Deep Sea Research, 21(9): 767-771.

Behrendt, H. 1996. Berechnung der Nährstoffeinträge aus Flußgebieten des Landes Mecklenburg-Vorpommern. Schriftenreihe des Landesamtes für Umwelt und Natur: 64 pp.

Benson, R.L., I.D. McKelvie, B.T. Hart, Y.B. Truong \& I.C. Hamilton. 1996. Determination of total phosphoruus in waters and waste waters by on-line UV/thermal induced digestion and flow injection analysis. Analytica Chimica Acta, 326: 29-39.

Bolier, G., M.C.J. de Koningh, J.C. Schmale \& M. Donze. 1992. Differential luxury phosphate response of planktonic algae to phosphorus removal. Hydrobiologia, 243/244: 113-118.

Boström, B. 1984. Potential mobility of phosphorus in different types of lake sediments. Int. Rev. ges. Hydrobiol., 69/4: 457-474.

Boström, B., J.M. Andersen, S. Fleischer \& M. Jansson. 1988. Exchange of phosphorous across the sediment-water interface. Hydrobiologia, 170: 229-244.

Canfield, D.E. \& M.V. Hoyer. 1988. Influence of nutrient enrichment and light availability on the abundance of aquatic macrophytes in Florida Streams. Can. J. Fish. Aquat. Sci., 45/8: 1467-1472.

Carper, G.L. \& R.W. Bachmann. 1984. Wind resuspension of sediments in a prairie lake. Can. J. Fish. Aquat. Sci., 41/12: 1763-1767.

Cembella, A.D., N.J. Anita \& P.J. Harrison. 1984. The utilization of inorganic and organic phosphorus compounds nutrients by eukaryotic microalgae - a multidisciplinary perspective. Part 1. Crit. Rev. Microbiol., 10: 317-391.

Cotner, J.B. \& R. Wetzel. 1992. Uptake of dissolved inorganic and organic phosphorus compounds by phytoplankton and bacterioplankton. Limnol. Oceanogr., 37: 232-243.

Davelaar, D. 1993. Ecological significance of bacterial polyphosphate metabolism in sediments. Hydrobiologia, 253: 179-192.

DEV 1985. Deutsche Einheitsverfahren zur Wasser-, Abwasser- und Schlammuntersuchung. Bestimmung des Chlorophyll- $a$-Gehaltes von Oberflächengewässern. DIN 38412.

Dorich, R.A., D.W. Nelson \& L.E. Sommers. 1985. Estimating algal available phosphorus in suspended sediments by chemical extraction. J. Environ. Qual., 14: 400-404.

Dressler, M., U. Selig, W. Dörfler, S. Adler, H. Schubert \& T. Hübener. (2006). The last ca 4800 years palaeolimnology of lake Dudinghausener See (North Germany): environmental history and society development. Quaternary Research: (in press).

Edler, L. 1979. Recommendations on methods for marine biological studies in the Baltic Sea. Phytoplankton and Chlorophyll. BMB publication, No. 5.

Eixler, S., U. Karsten \& U. Selig. 2005. Phosphorus storage in Chlorella vulgaris (Trebouxiophyceae, Chlorophyta) cells and its dependence on phosphate supply. Phycologia, 45(1): 53-60.

Fabre, A., A. Qotbi, A. Dauta \& V. Baldy. 1996. Relation between algal available phosphate in the sediments of the River Garonne and chemically-determined phosphate fractions. Hydrobiologia, 335: 43-48.

Feuillade, J., G. Bielicki \& J. Renou. 1995. 31P-NMR study of natural phytoplankton samples. Hydrobiologia, 300/301: 391-398.

Findlay, R.H., G.M. King \& L. Watling. 1989. Efficacy of phospholipid analysis in determining microbial biomass in sediments. Appl. Envir. Microbiol., 55: 2888-2893.
Fitzgerald, G.P. \& T.C. Nelson. 1966. Extractable and enzymatic analysis for limiting or surplus phosphorus in algae. J. Phycol., 2: 32-37.

Geider, R.J. \& L. La Roche. 2002. Redfield revisited: variability of $\mathrm{C}: \mathrm{N}: \mathrm{P}$ in marine microalgae and its biochemical basis. Eur. J. Phycol., 37: 1-17.

Hamilton, D.P. \& S.F. Mitchell. 1997. Wave-induced shear stress, plant nutrients and chlorophyll in seven shallow lakes. Freshwat. Biol., 38: 159-168.

Hecky, R.E., P. Campbell \& L.L. Hendzel. 1993. The stoichiometry of carbon, nitrogen, and phosphorus in particulate matter of lakes and oceans. Limnol. Oceanogr., 38: 709-724.

Hecky, R.E. \& P. Kilham. 1988. Nutrient limitation of phytoplankton and marine environments: A review of recent evidence on the effects of enrichment. Limnol. Oceanogr., 33: 796-822.

House, W.A., F.H. Denison \& P.D. Armitage. 1995. Comparison of the uptake of inorganic phosphorus to a suspended and stream bed-sediment. Wat. Res., 29: 767-779.

Hupfer, M., R. Gächter \& R. Giovanoli. 1995. Transformation of phosphorus species in settling seston and during early sediment diagenesis. Aquat. Sci., 57: 305-324.

Kenney, W.F., C.L. Schelske \& A.D. Chapman. 2001. Changes in polyphosphate sedimentation: a response to excessive phosphorus enrichment in a hypereutrophic lake. Can. J. Fish. aquat. Sci., 58: 879-887.

Kilham, S.S., D.A. Kreeger, C.E. Goulden \& S.G. Lynn. 1997. Effects of nutrient limitation on biochemical constituents of Ankistrodesmus falcatus. Freshwat. Biol., 38: 591-596.

Kjeldstad, B., M. Heldal, H. Nissen, A. S. Bergan \& K. Evjen. 1991. Changes in polyphosphate composition and localization in Propionibacterium acne after nearultraviolet irradiation. Can. J. Microbiol., 37: 562-567.

Kornberg, A. 1995. Inorganic polyphosphate: toward making a forgotten polymer unforgettable. J. Bacteriol., 177: 491-496.

Kulaev, I.S. \& V.M. Vagabov. 1983. Polyphosphate metabolism in microorganisms. Adv. Microb. Physiol., 24: 83-171.

LAWA. 1998. Gewässerbewertung - Stehende Gewässer Richtlinie zur Bewertung von natürlich entstandenen Seen nach trophischen Kriterien. Länderarbeitsgemeinschaft Wasser: $74 \mathrm{pp}$.

Lawrence, B.A., C. Suarez, A. DePina, E. Click, N.H. Kolodny \& M.M. Allen. 1998. Two internal pools of soluble polyphosphate in the cyanobacterium Synechocystis sp. strain PCC 6308: an in vivo super(31)P NMR spectroscopic study. Arch. Microbiol., 169: 195-200.

Lean, D.R.S. 1984. Metabolic indicators for phosphorus limitation. Verh. int. Ver. Limnol., 22: 211-218.

Malcolm-Lawes, D.J. \& H.W. Koon. 1990. Determination of orthophosphate in water and soil using a flow analyzer. Analyst, 15: 65-67.

Miyata, K. \& A. Hattori. 1986. A simple fractionation method for determination of phosphorus components in phytoplankton: application to natural populations of phytoplankton in summer surface waters of Tokyo Bay. $J$. Oceanogr. Soc. Japan, 42: 255-265.

Nakamura, T., H. Yamaguchi \& S. Ohashi. 1980. Problems on use of autoanalyzer for condensed phosphates. J. UOEH, (Japan) 2: 199-205.

Napolitano, G.E. 1994. The relationship of lipids and chlorophyll measurements in freshwater algae and periphyton. J. Phycol., 30: 943-950.

OECD. 1982. Eutrophications of waters. Monitoring, Assessment and Control. OECD report, OECD Paris: $154 \mathrm{pp}$.

Pacini, N. \& R. Gächter. 1999. Speciation of riverine particulate phosphorus during rain events. Biogeochemistry, 47: 87-109.

Psenner, R., R. Pucsko \& M. Sager. 1984. Die Fraktionierung organischer und anorganischer Phosphorbindungen von 
Sedimenten - Versuch einer Definition ökologisch wichtiger Fraktionen. Arch. Hydrobiol. Suppl., 70: 111-155.

Reynolds, C.S. \& P.S. Davies. 2001. Sources and bioavailability of phosphorus fractions in freshwaters: a British perspective. Biol. Rev. Camb. Philos. Soc., 76: 27-64.

Rhee, G.Y. 1973. A continuous culture study of phosphate uptake, growth rate and polyphosphate in Scenedesmus sp. J. Phycol., 9: 495-506.

Sas, H. 1989. Lake restoration by reduction of nutrient loading: expectations, experiences, extrapolations. Academia Verlag Richarz, Sankt Augustin, 497 pp.

Schelske, C.L. \& L. Sicko-Goad. 1990. Effect of chelated trace metals on phosphorus uptake and storage in natural assemblages of Lake Michigan phytoplankton. J. Great Lakes Res., 16: 82-89.

Schelske, C.L. 1994. Assessing nutrient limitation in a hypereutrophic lake. Lake Reserv. Manage., 9: 112 pp.

Selig, U., T. Hübener \& M. Michalik. 2002. Dissolved and particulate phosphorus forms in a eutrophic shallow lake. Aquat. Sci., 64: 97-105.

Selig, U. \& G. Schlungbaum. 2003. Characterisation and quantification of phosphorus release from profundal bottom sediments in two dimictic lakes during summer stratification. J. Limnol., 62(2): 151-162.

Selig, U. 2003. Particle size-related phosphate binding and Prelease at the sediment-water interface in a shallow German lake. Hydrobiologia, 492: 107-118.
Selig, U., T. Hübener, R. Heerkloss \& H. Schubert. 2004. Vertical gradient of nutrients in two dimictic lakes influence of phototrophic sulfur bacteria on the nutrient balance. Aquat. Sci., 66(3): 247-256.

Shifrin, N.S. \& S.W. Chisholm. 1981. Phytoplankton Lipids Interspecific Differences and Effects of Nitrate, Silicate and Light-Dark Cycles. Phycologia, 17: 374-384.

Sommer, U. 1989. Nutrient status and nutrient competition of phytoplankton in a shallow, hypertropic lake. Limnol. Oceanogr., 34: 1162-1173.

Stookey, L.L. 1970. Ferrozine - A New Spectrophotometric Reagent for Iron. Analyt. Chem., 42: 779-781.

Tartari, G. \& G. Biasci. 1997. Trophic status and lake sedimentation fluxes. Wat. Air Soil Pollut., 99: 523-531.

Urabe, J. 1993. Seston stoichiometry and nutrient deficiency in a shallow eutrophic pond. Arch. Hydrobiol., 126: 417428.

Utermöhl, H. 1958. Zur Vervollkommnung der quantitativen Phytoplankton-Methodik. Verh. int. Ver. Limnol., 9: 1-38.

Verardo, D.J., P.N. Froelich \& A. McIntyre. 1990. Determination of organic carbon and nitrogen in marine sediments using Carlo-Erba Na-1500 analyzer. Deep Sea Res., 37: 157-165.

Young, T.C. \& J.V. DePinto. 1982 Algal availability of particulate phosphorus from diffuse and point sources in the lower great-lakes basin. Hydrobiologia, 91/2: 111-119. 